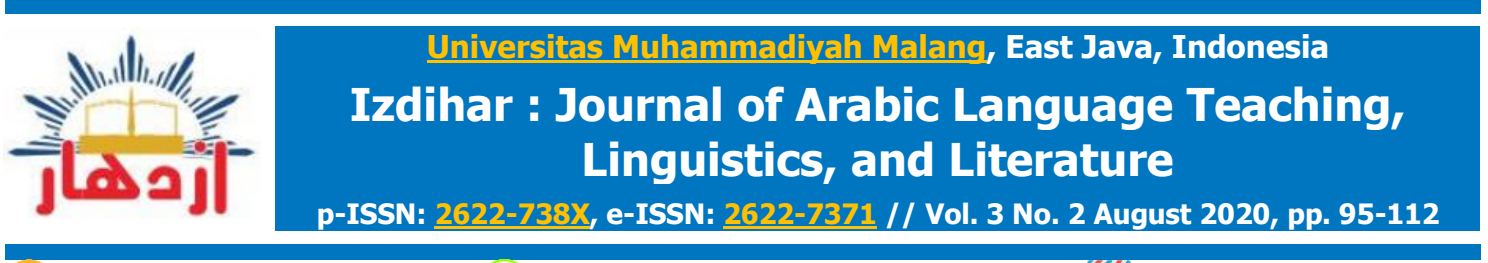

doi

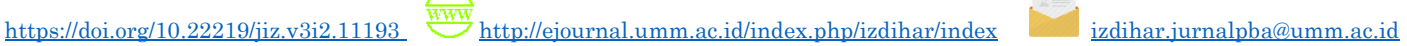

\title{
Characteristic of Teaching Materials for Arabic Reading Skill with Inductive Approach
}

\author{
Himatul Istiqomah a,1, Mohammad Jawad Habeeb al-Badranib,2 \\ aUniversitas Negeri Malang, Indonesia, bUniversity of Basrah, Iraq \\ 1himastiq@gmail.com*,2prof.dr.mohammdalbdrany@gmail.com
}

\section{ARTICLE INFO}

\section{Article History:}

Submitted: $10 / 05 / 2020$

Revised: $13 / 07 / 2020$

Accepted: $18 / 08 / 2020$

Published: $31 / 08 / 2020$

\section{*Corresponding}

Author:

Name: Himatul

Istiqomah

Email:

himastia@gmail.com

\begin{abstract}
Himmati is deliberately created as a textbook modification to recognize the Qur'an prepared for beginners. This research aimed to describe the characteristics of teaching material contained in Himmati. This research was a qualitative approach and content analysis of the perspective of Thu'aimah. It also belonged to library research with the main data source is a book, named Himmati: Modifikasi Pembelajaran Dasar Mengenali al-Qur'an from volume 1 to volume 5 . The results showed that: 1) Generally, the teaching materials in Himmati were divided into 5 volumes which were presented inductively, namely the introduction of letters, words, tajweed, gharib, and verses in the Qur'an. Specifically, the teaching materials in Himmati were divided into 7 volumes which were presented with examples from the Qur'an and colored in the order of the frequency of visible light, from red to violet. The $1^{\text {st }}$ volume focused on pronunciation, the $2^{\text {nd }} \mathrm{A}$ volume was on short vowels, long vowels, nunation (tanwin), and original sukuun, the $2^{\text {nd }} \mathrm{B}$ volume was on non-original sukuun and shadda, the $3^{\text {rd }} \mathrm{A}$ volume was on the law of nuun sukuun, nunation, germination nuun and miim, the $3^{\text {rd }} B$ volume was on the law of miim sukuun, definite article $a l$, and madd, the $4^{\text {th }}$ volume was on the rule of exception, and the $5^{\text {th }}$ volume was on the stop sign. The teaching materials in Himmati presented for beginners level.
\end{abstract}

Copyright (C) 2020, Istiqomah et al This is an open access article under the CC-BY-SA license

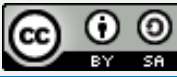

Himmati; Teaching Materials; Thu'aimah

\section{Keyword}

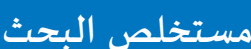

إن "همّتي" قد تم تنظيمه عمدا كتعديل الكتب التعليمية للتعارف بالقرآن للمبتدئين. ويهدف هذا البحث لوصف خصيائص المواد التعليمية في الكتاب همّتي .كان نوع هذا البحث هو منهج كيفي وتحليل المضيمون عند نظرية طعيمة. و كان هذا البحث بحثثا مكتبية البيا مع مصدر

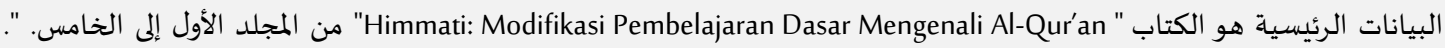

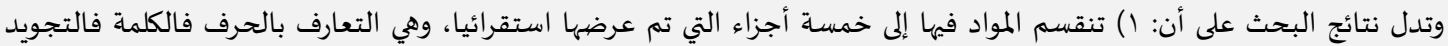

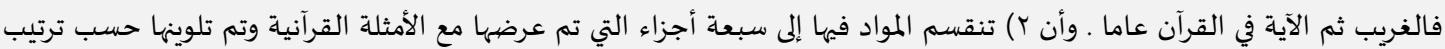

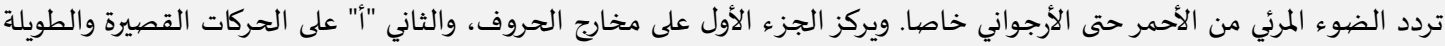

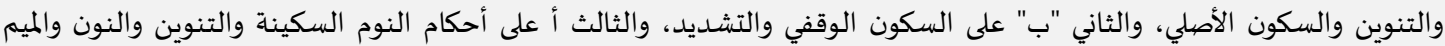

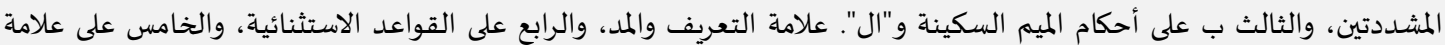
الوقف. وتعدّ المواد فيها للمستوى المبتدئين.

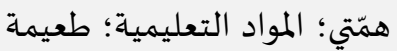
كلمات أساسية

Please cite this article as Istiqomah, H., Al-Badrani, M. J. H. (2020). Characteristics of Teaching Materials for Arabic Reading Skill with Inductive Approach. Izdihar : Journal of Arabic Language Teaching, Linguistics, and Literature, 3(2), 95-112. DOI: https://doi.org/10.22219/jiz.v3i2.11193 


\section{INTRODUCTION}

The Qur'an is one of the heavenly books that God Almighty revealed to the Prophet Muhammad as the guidance of the converted men. It was revealed in Arabic, so the believers use their minds to understand what is in the verses (Effendy, 2013). Before they reach an understanding of the meaning, of course, they must read the verses. Therefore, learning to read the Qur'an is very important and needed.

Even so, there are still many Muslims who have not been able to read the Qur'an well. Based on the results of previous research, there was found many students in several Islamic universities in Indonesia with low Qur'an reading skills (Alhamuddin, Hamdani, Tandika, \& Adwiyah, 2018; Otaya, Anwar, \& Husain, 2019). There was also found that many students in several high schools were not yet skilled in reading the Qur'an correctly and smoothly (Supriyadi \& Julia, 2019).

To resolve this problem, many scholars create textbooks for reading the Qur'an. Several textbooks that have been published in Indonesia such as Qira'ati by Dahlan Salim Zarkasyi (1989), Iqra' by Asaad Humam (1990), Tilawati by Hasan Sadzili, M. Thohir Al-Ali, Masrur Masyhud, and Ali Muaffa (2000), Yanbu'a, by Ulil Albab, Ulin Nuha, and M. Manshur Maskan (2004), etc.

To prepare a textbook, several things must be considered. One of them is the presentation of teaching materials (Thu'aimah, 1958). The existence of teaching materials is very important in learning activities (Anggara \& Habib, 2018). The teaching material is one of the external factors that influence the motivation to learn and affect the success of the teaching and learning process (Islam, 2015; Istiqomah \& Mahliatussikah, 2019). Therefore, many teachers do reorganization, replacement, and addition to develop teaching materials. A good textbook is one that has material that is suited to the learner's needs and the character values (Cloonan \& Fingerest, 2020; Munif, 2018).

After the researcher reviewed the teaching materials in several textbooks for reading the Qur'an, she made some modifications in a new book entitled Himmati: Modifikasi Pembelajaran Dasar Mengenali al-Qur'an. Himmati is a textbook that aimed to help the beginner for learning to read the Qur'an (Istiqomah, 2019). In its preparation process, it was welcomed and evaluated by several teams of Arabic and the Qur'an experts, a fellow of Ashoka Foundation, a design expert, and a psychologist.

Himmati belongs to a new textbook. It is a model of the development the Qur'an learning book that presented in a comprehensive and complete manner. Through this research, the researcher aimed to describe the characteristics of teaching materials in it. She also aimed to offer it to the public as a new prototype for a textbook to read the Qur'an for beginners. So, it can be used for the Qur'an 
educational institutions, both teachers and students, formal and nonformal. It also can be used for many people in need.

\section{METHOD}

This research belonged to qualitative research with a qualitative approach and qualitative data. This also belonged to library research with the main data source is a book, named Himmati: Modifikasi Pembelajaran Dasar Mengenali alQur'an from volume 1 to volume 5 . This research used the researcher herself as a research instrument or called human instrument and used documentation techniques to collect data.

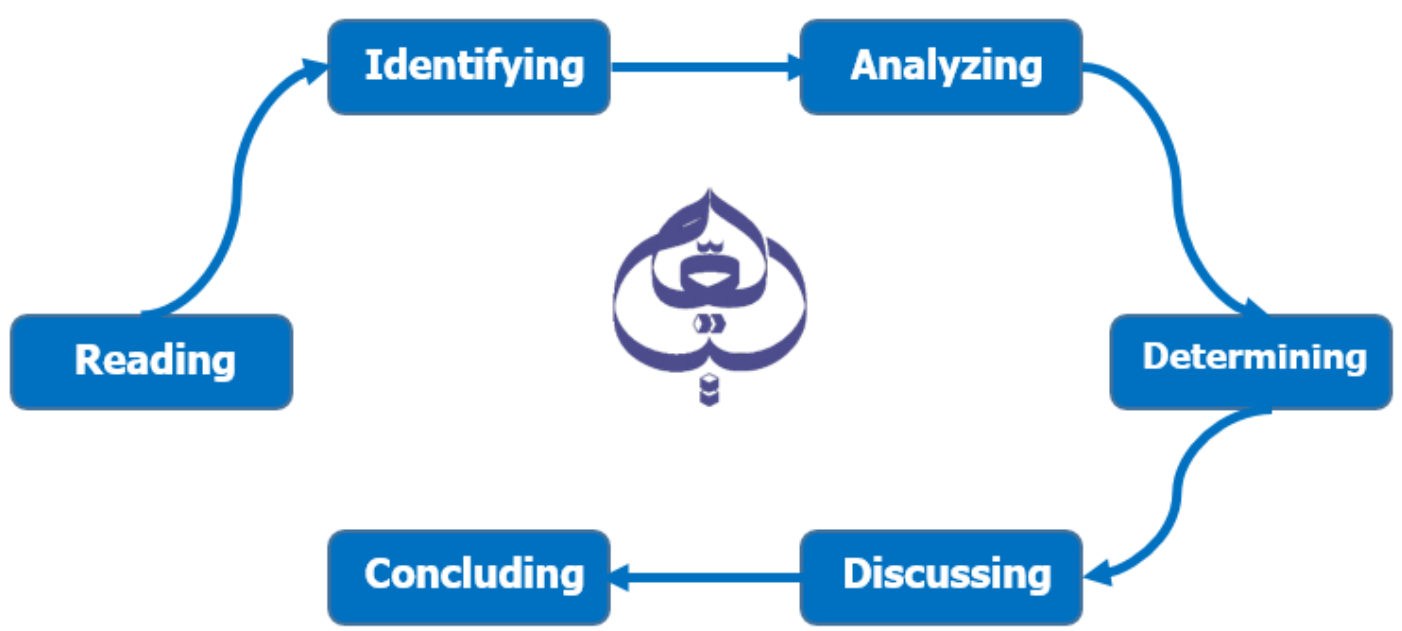

Figure 1: Step of the research

Figure 1 illustrated that the steps were used in this research are follows. 1) Reading Himmati from volume 1 to volume 5. 2) Identifying the teaching materials in each the volume of Himmati. 3) Analyzing characteristics of the teaching materials in each volume of Himmati. 4) Determining characteristics of the teaching materials in each volume of Himmati with some previous theories and previous research. 5) Discussing the findings into description text. 6) Concluding the result based on the data findings.

While the technique to analyze data that used in this research belonged to Thu'aimah's perspective. As he said in his book, analyzing the teaching materials can be done by asking some questions. How was the teaching materials in Himmati presented? What was presented in each volume? For who the teaching materials was presented? (Thu'aimah, 1958). 


\section{RESULTS \& DISCUSSION}

The Characteristic of Teaching Material in Himmati Generally

Thu'aimah said in his book that teaching material is a collection of educational experiences, information, and desired facts to develop the learner's competencies and to acquire diverse skills completely as found in the educational curriculum (Farid, 2018). The teaching materials can be presented with various forms, such as reading, listening, or merge of both readings and listening (AlUshaili, 2002). The teaching materials, especially in the postmodern era like now, also can be presented with blending between script and picture by using modern technology (Wahab, 2015).

The teaching material has its functions which so important. It prepares the basis for the lesson's contents. It makes the teaching competencies equally. It can be main information sources besides the teacher. It also makes the learners study easier (Hakim, 2019)

Al-Rajihi (1995) said in his book that the characteristics of teaching materials included the selection and presentation. According to Thu'aimah's perspective, there were found three main points of discussion as findings in this research. Namely, displaying the teaching material in Himmati generally, displaying the teaching materials in Himmati specifically, and displaying the target of the teaching materials in Himmati.

Based on the preface of Himmati, generally, the teaching materials in it are divided into 5 volumes. The $1^{\text {st }}$ volume is about the introduction of letters in the Qur'an. The $2^{\text {nd }}$ volume is about the introduction of the word in the Qur'an. The $3^{\text {rd }}$ volume is about the introduction of tajweed in the Qur'an. The $4^{\text {th }}$ volume is about the introduction of gharib in the Qur'an. The $5^{\text {th }}$ volume is about the introduction of verse in the Qur'an.

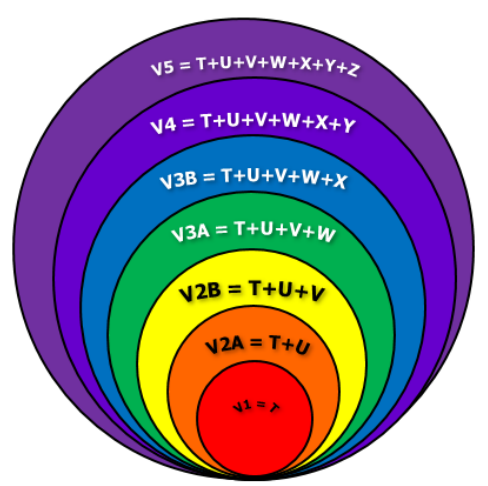

Figure 2: A cyclic gradation in Himmati

Figure 2 illustrated that the teaching materials arranged with adopting cyclic gradation (Al-Rajihi, 1995; Corder, 1973). The letters T, U, V, W, X, Y, and $Z$ were symbols represented a point of teaching material in each volume of 
Himmati. The first level limited to point $T$. Then, it was added with point $U$ in the second level. Afterward, points $T$ and $U$ added and used clearer in the next level until the peak level.

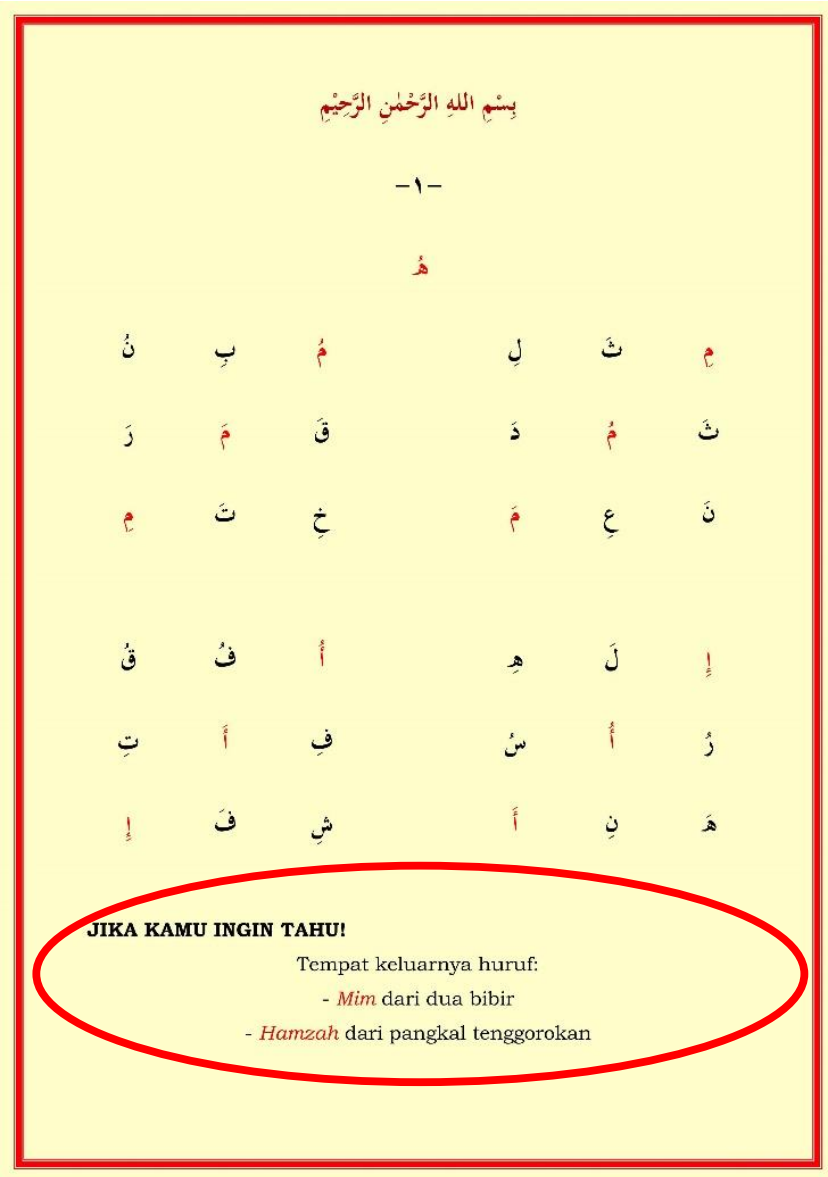

Figure 3: The teaching material presented inductively

Generally, Figure 3 illustrated that the teaching materials in Himmati were presented inductively. There was displaying several examples then followed by material description or concept explanation. As the theory that in the inductive approach, teaching begins with the presentation of several examples that contain a concept. Furthermore, learners will be guided to try to formulate, model, and or infer the basic concepts of the displaying (Effendy, 2005; Mahjoob, 2015). Some previous researches prove that this approach is considered more effective than the deductive approach in teaching (Benitez-Correa, Gonzalez-Torres, Ochoa-Cueva, \& Vargas-Saritama, 2019; Mallia, 2014). 


\section{The Teaching Material in Himmati Specifically}

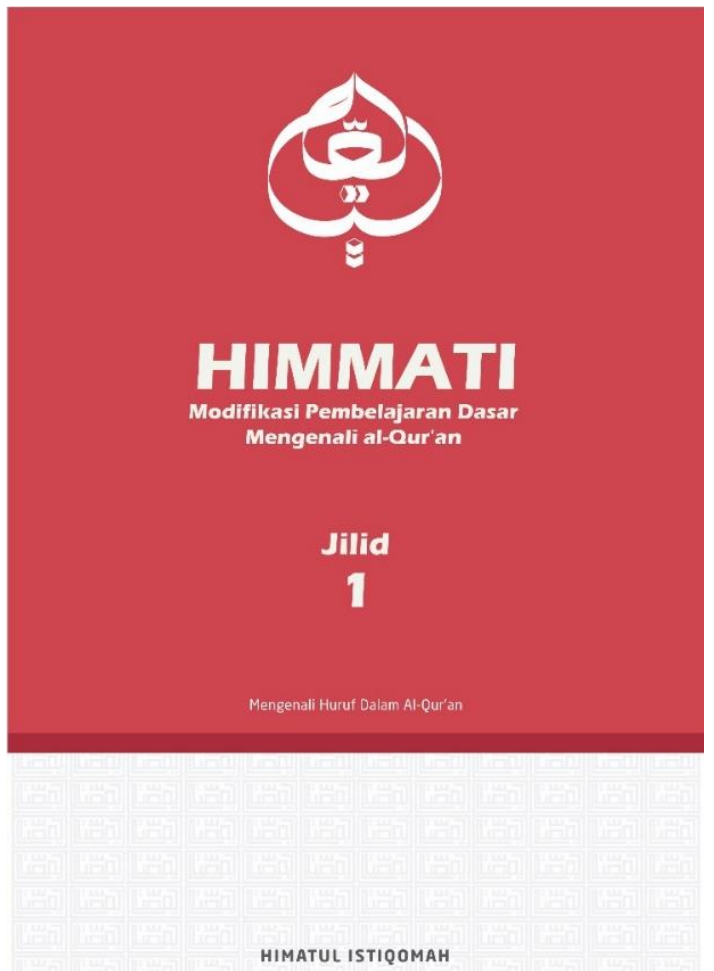

Figure 4: The $1^{\text {st }}$ volume of Himmati (red)

Specifically, the teaching materials in Himmati were divided into 7 volumes. Figure 4 illustrated that the $1^{\text {st }}$ volume focused on the introduction of letter. There was introduced about how to pronounce Hijaiyah letters correctly one by one according to the place of exit (makharijul huruf).

Besides that, Hijaiyah letters in the first volume were presented based on special order. There was begun with a letter that easiest to pronounce it, named letter miim (२). There was ended with a letter that most difficult to pronounce it, named letter Daad (ض) (Manshur, 1980, p. 185). While the others arranged based on the amount of their use in the Qur'an (Al-Daq, 2013). Thus, the arrangement Hijaiyah letters in Himmati is miim ( $(\rho)$, hamza $(s)$, laam (J), nuun (ن), waaw (و), yaa'(ي), haa'(0), taa'(ت), raa'(ر), baa'(ب), kaaf(ك), 'ayn (ع),

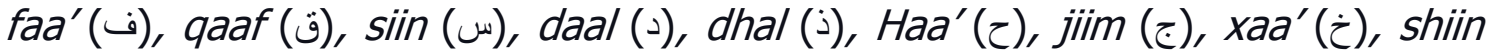
(ش), saad (ص), zaay (j), thaa'(ن), Taa'(b), ghayn (غ), Zaa'(ظ), and Daad(ض).

According to figure 3 above, each page in this volume presented the introduction of two main letters. Each main letter repeated six times, three times written on the right side and three times on the left side. Each main letter was written with two other letters which formed one word in the Qur'an. Thus, the introduction of one letter would introduce six words in the Qur'an. The introduction of these letters also accompanied by vowels directly, with the 
sequence starting from the strong, the middle, then the weak vowel, namely kasra, damma, then fatha (Ryding, 2005).

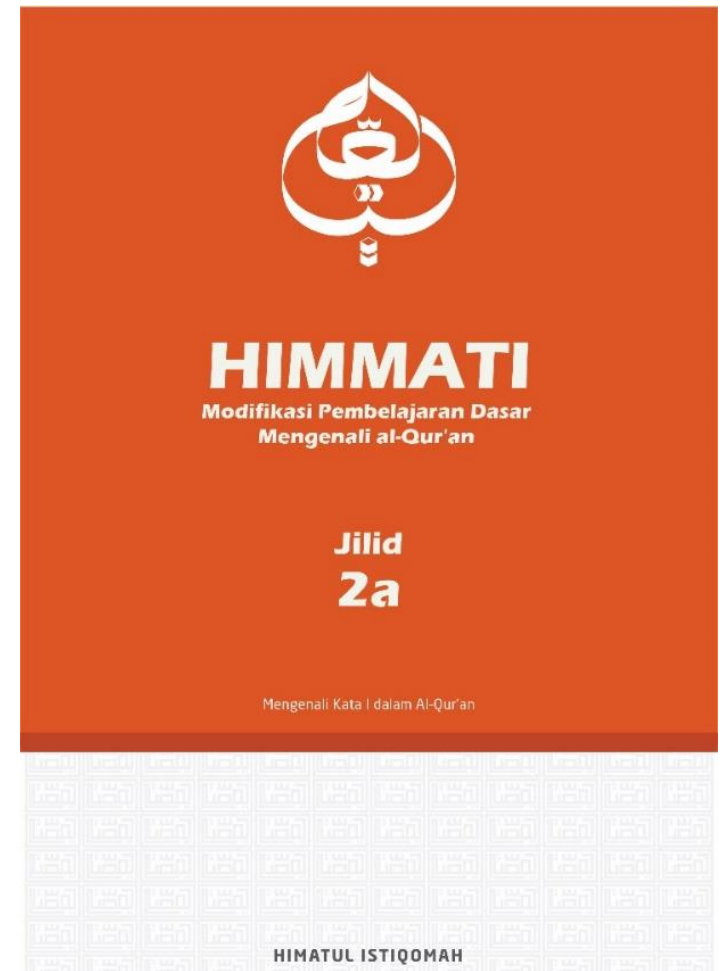

Figure 5: The $2^{\text {nd }} A$ volume of Himmati (orange)

Figure 5 illustrated that the $2^{\text {nd }} \mathrm{A}$ volume introduced word section 1 in the Qur'an. It focused on the introduction of the words with short vowels, long vowels, nunation, and then with original sukuun. Nunation is Arabic tanwin (Azaz, 2019). It is a suffix " $N$ " that follows short vowels (Mijlad \& El Younoussi, 2019). It is always at the end of the word (Zaghouani et al., 2016).

The introduction of the word with short vowels was presented just in one page. Because the short vowels were presented in the previous volume. The introduction of long vowels was starting from the strong $-i i$, the middle $-u(t$, then the weak vowel with alif Tawiila (I) then alif maqSura (ى)-aa-, which each type of vowel in one page.

The introduction was continued with nunation starting from kasra with nunation -in-, damma with nunation-un-, and Fatha with nunation-an-, which each type of nunation in one page. Then, the combination of all types of nunation also on one page. There were also presented some familiar words in Muslim's daily activities.

After that, there was continued with original sukuun, an absence of vowel in the middle of the word (Ryding, 2005). There was started from original sukuun on all of Hijaiyah letters, original sukuun on Qalqala letters - qaaf(ق), Taa'(b), 
baa'(ب), jiim (ج), and daal(د) -, then original sukuun on Layyin letters -ay (وَ) and $a w(\xi)-$.

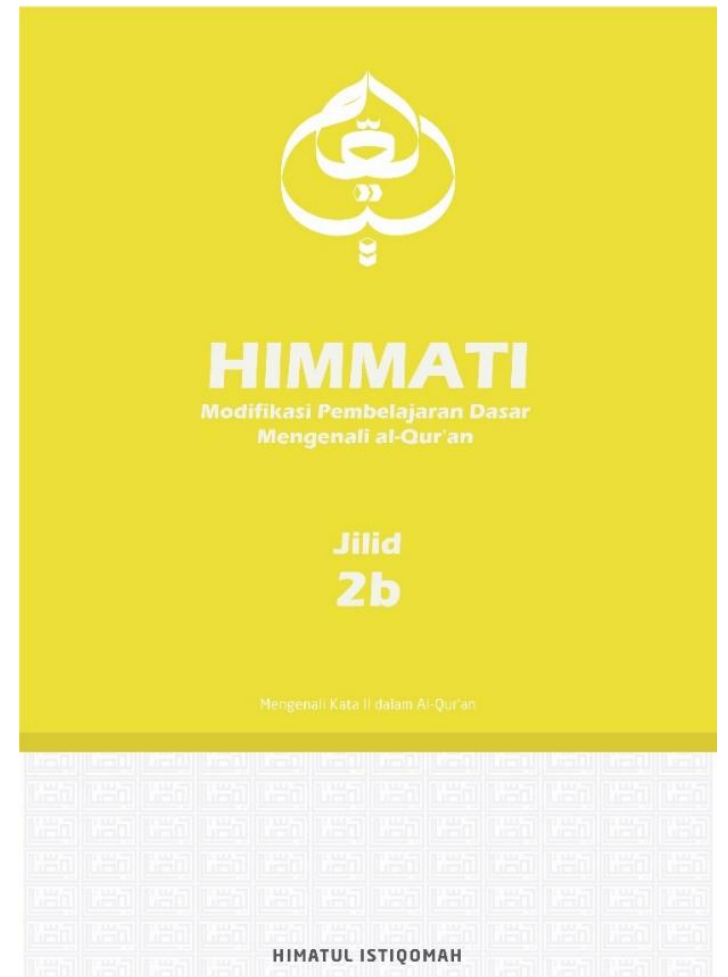

Figure 6: The $2^{\text {nd }} B$ volume of Himmati (yellow)

Figure 6 illustrated that the $2^{\text {nd }} \mathrm{B}$ volume introduced word section 2 in the Qur'an. It focused on the introduction of the words with non-original sukuun and shadda. Non-original sukuun is an absence of vowel on the last letter of the word which paused. Shadda is phonological germination (Marzouk \& Kareh, 2018). It is a sign of double consonants that it's sound repetitive (Zerrouki, Shquier, Balla, Bousbia, Sakraoui, \& Boudardara, 2019).

The introduction in this volume was started from non-original sukuun on the Hijaiyah letters, non-original sukuun on taa' ta'nith $(ت)$, haa'(0), then taa' marbuTaa (*), which each type of them in one page. Then, the combination of all types of taa' ta'nith $(ت)$, haa'(0), and taa' marbuTaa (:) also on one page. The introduction was continued with non-original sukuun on Qalqala letters.

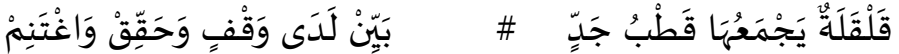

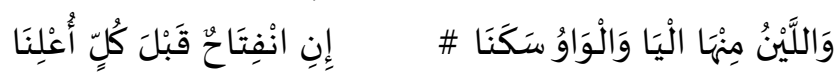

According to the information written by Nabhan translated by Al-Samarani (n.d.), the poem verse said that Hijaiyah letters which include Qalqala letters are 
qaaf (ق), Taa'(b), baa'(ب), jiim (ج), and daal (د) -. Then, it is continued with non-original sukuun on all of the Hijaiyah letters which preceded by madd or long vowel (ii( $)$, uu (j), then $a a(1))$, which each type of them in one page. Then, the combination of non-original sukuun was on all three long vowels.

There was continued with non-original sukuun on Qalqala letters -qaaf (ق), Taa'(b), baa'(ب), jiiim (ج), and daal (د) - which preceded by madd or long

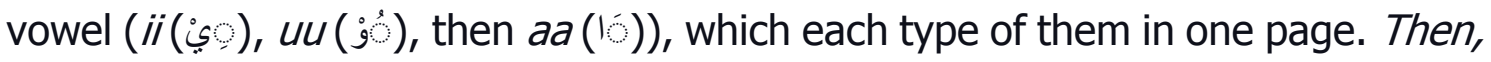
the combination of non-original sukuun was on all three long vowels. It was continued with non-original sukuun on Layyin letters.

According to the information written by Al-Jamzuri translated by Al-Maraqi (n.d.), the poem verse said that Layyin letter is the letter yaa'(s) or waaw (g) with original sukun that comes after fatha. The presentation of Layyin letters starting from ay (jos) then aw $(\dot{9})$, which each type of them in one page. Then, the combination of non-original sukuun on both of the types. The last, there was presented non-original sukuun with fatha nunation (1). Then, there was continued with germination () on each Hijaiyah letter.

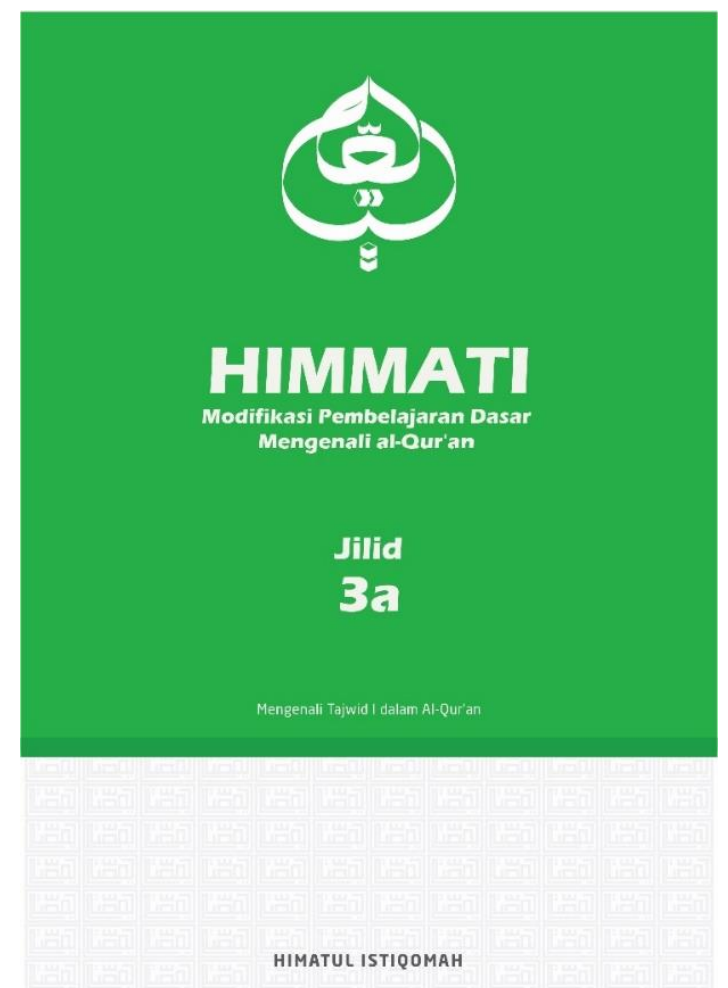

Figure 7: The $3^{\text {rd } A}$ volume of Himmati (green)

Figure 7 illustrated that the $3^{\text {rd }} \mathrm{A}$ volume introduced tajweed section 1. Tajweed is scientific about rules to read the Qur'an with ensuring pronunciation, recitation, and interpretation correctly (Taib, Yusof, Jamil, Aris, \& Satari, 2016; Yousfi \& Zeki, 2017). Firstly, there focused on the law of germination nuun (ن) 
then germination miim ( $)$, which each of them presented on one page. Then, it followed by the combination of germination nuun and germination miim on one page.

The teaching materials was continued with the law of nuun sukuun and nunation when one of them met the Hijaiyah letters. Both of them had five laws in the reading, namely: idhar, idgham bighunnah, idgham bilaghunnah, iqlab, and ikhfa'. Each of the reading law was presented on one page which focused on nuun sukuun, one page which focused on nunation, then one page which presented the combination of nuun sukuun and nunation. Thus, each reading law was presented on three pages.

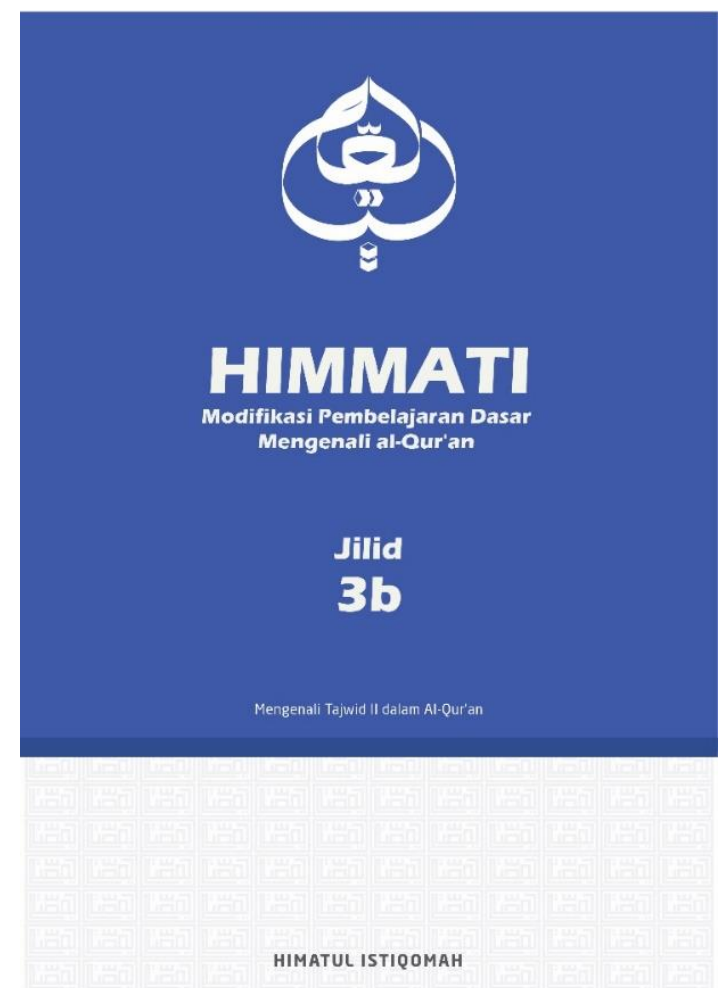

Figure 8: The $3^{\text {rd } B}$ volume of Himmati (blue)

Figure 8 illustrated that the $3^{\text {rd } B}$ volume introduced tajweed section 2 . Firstly, the introduction focused on the law of miim sukuun when met the Hijaiyah letters. It had three laws in the reading, namely: ikhfa' syafawi, idgham ma'al ghunnah, and idhar syafawi. Then, it was followed by idhar syafawi harshi.

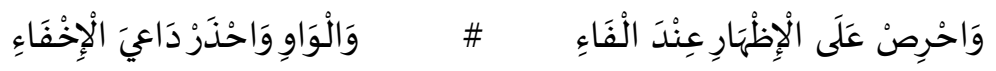

According to the information written by Nabhan which was translated by AlSamarani (n.d.), the poem verse said that idhar syafawi harshi is the reading law when miim sukuun met the letter faa' (ف) or waaw (g). It must be read more clearly than idhar syafawi. 
The teaching materials was continued with the law of definite article al when met the Hijaiyah letters. It had two laws in the reading, namely: idhar qamariyah and idgham syamsiyah. A/ qamariyah as moon letters did not absorb or assimilate the sound "I" in hijaiyah letter of the definite article. Hijaiyah letters

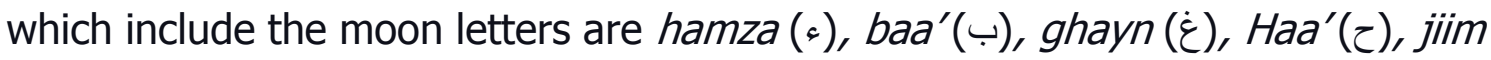

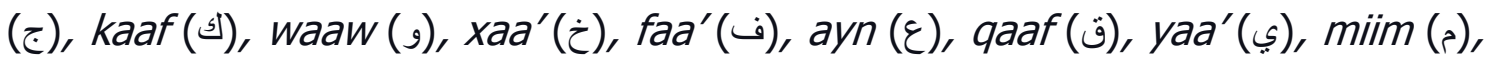
and $h^{\prime} a^{\prime}(\circ)$ (Munjiah, 2012).

Al syamsiyah as sun letters absorb or assimilate each letter at the beginning of the word. Hijaiyah letters which include the sun letters are $\operatorname{Taa}^{\prime}(b)$,

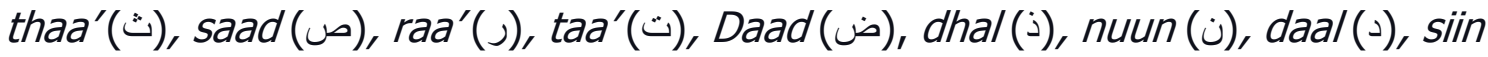
(w), Zaa'(b), zaay (j), shiin (ش), and lam (J) (Munjiah, 2012). It is usually marked by germination. Thus, the real difference between al qamariyah and al syamsiyah is the existence of germination on the sun letters and absence of germination on the moon letters. Each of them was presented on one page.

The next, there was continued with the law of madd, begun from madd thabi'i or madd Ashli then madd far'i. The introduction of madd far'i consisted of madd wajib muttashil, madd jaiz munfashil, madd lazim kilmi mutsaqqal, madd lazim kilmi mukhaffaf, madd 'aridl lissukun, madd shilah qashirah, madd shilah thawilah, madd layyin, madd 'iwadl, madd badal, madd farqi, madd tamkin, madd lazim kharfi mutsaqqal, then madd lazim kharfi mukhaffaf. Each of them was presented on one page.

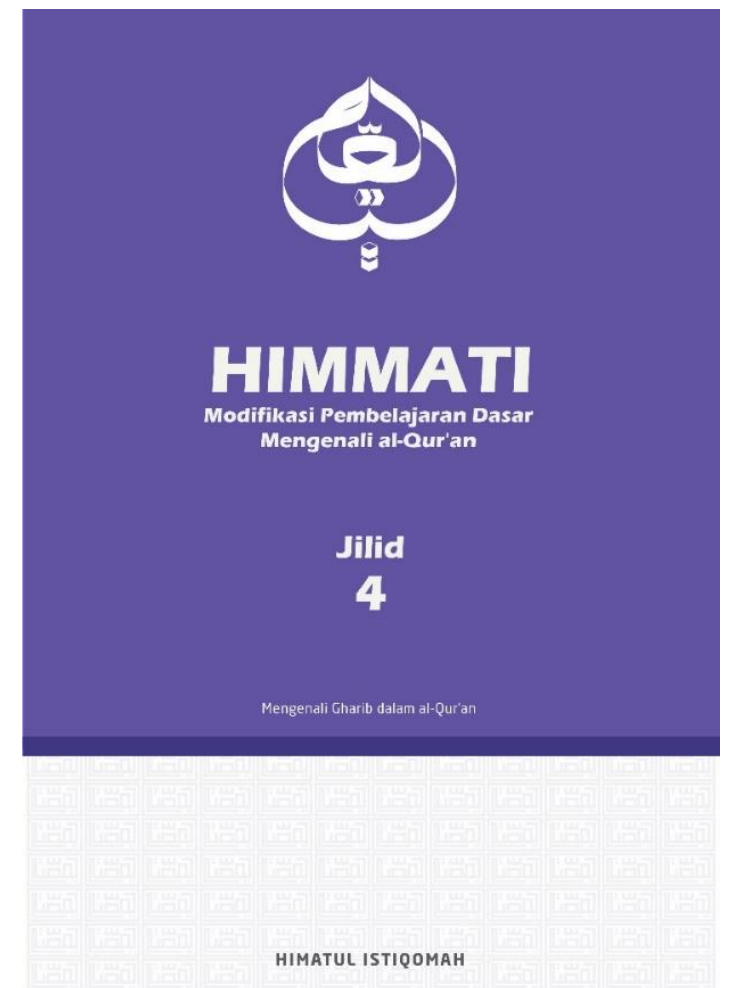

Figure 9: The $4^{\text {th }}$ Volume of Himmati (Purple)

Please cite this article as Istiqomah, H., Al-Badrani, M. J. H. (2020). Characteristics of Teaching Materials for Arabic Reading Skill with Inductive Approach. Izdihar : Journal of Arabic Language Teaching, Linguistics, and Literature, 3(2), 95-112. DOI: https://doi.org/10.22219/jiz.v3i2.11193 
Figure 9 illustrated that the $4^{\text {th }}$ volume introduced rule of exception in the Qur'an, named gharib. This rule was different from the usual rules in the Qur'an that also important to be learned, so reading the Qur'an can be clearer. According to Imam Ashim said by Hafs, it was begun with the introduction of imalah, isymam, tashil, naql, saktah, badal, madd and qashar.

Based on the previous research, the study about gharib belonged to Arabic phonology (Mahmoud \& Shaker, 2019). It was resulted by assimilation direct or indirect, regressive assimilation, progressive assimilation, assimilation of the way pronunciation, or metathesis that was influenced by the principle of power efficiency, ease theory, and balance theory (Adriana, 2017).

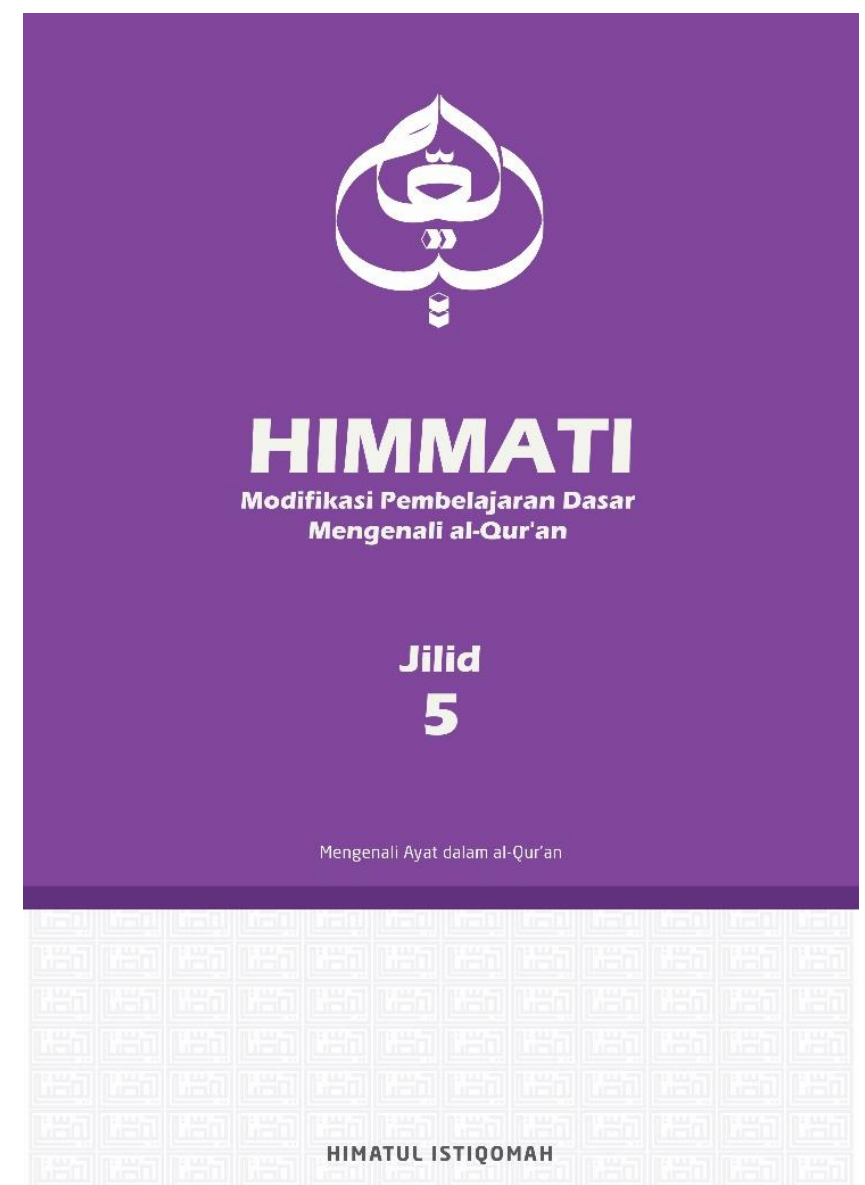

Figure 10: The $5^{\text {th }}$ volume of Himmati (violet)

Figure 10 illustrated that the $5^{\text {th }}$ volume introduced verse in the Qur'an, especially the verses about morals and attitude. There was the verses about orders to behave honestly, trustworthy, delivery information, smart in whatever situation, thankfully, patiently, to give to another, prohibitions to behave arrogantly, lie, orders to honor to the parents, to behave optimistically and the prohibitions to behave pessimistically, orders to get knowledge, then to behave 
independent and consistent (Istiqomah, 2019). Hopefully, everyone who learned this level will apply the moral values and attitudes in his daily life. This volume also focused on the stop sign included mandatory stop ( ()), common stop (b), possibility stop (ج), pleasant stop (قف), better stop (قلى), better connect (صلى), allowed stop (j), admissible stop (ص), bad stop (ق), then prevalent stop ( $(\mathrm{V})$ (Lubis, Lubis, \& Azmi, 2018).

According to figure 4 until figure 10 , specifically, the teaching materials in Himmati were colored in the order of the frequency of visible light from the lowest to the highest, from red, orange, yellow, green, blue, indigo, to violet (Bharadwaj, 2017). The purpose of this color order to pray for everyone who learned the Qur'an with Himmati, the knowledge level increased as much as frequency interval in the order of visible light (Istiqomah, 2019).

\section{The Target of the Teaching Materials in Himmati}

Based on the preface of Himmati, the teaching materials are presented to the beginners. Sometimes the beginners are determined by age or school grade (Yeomans-Maldonado, 2017). But, it is different from the criteria in Himmati's learners. Whoever has a low academic competency of reading the Qur'an named the beginner student. He can from the children, the young man, or the old man. He can from the lowest grade of school to the highest. He also can from the formal or non-formal institution. But, more priority is learning to read the Qur'an using Himmati is done by the learners together with the teachers as their supervisors.

Thu'aimah (1986) said that it is necessary at the beginner level to prepare the student for reading by providing him with a set of experiences that help him to read when starting with it. Some of these experiences include distinguishing letters, pronouncing words, knowing the symbol of what he reads afterward, etc.

The theory strengthens the presentation of teaching material in the book Himmati. The teaching materials in this book was arranged in such a way to enrich the learning experience of beginners, starting from the introduction of the elements contained in the al-Qur'an text to getting used to proper and correct pronunciation based on the proper rules.

\section{CONCLUSIONS}

Characteristic of teaching materials for reading Arabic skill in the book Himmati used inductive approach. It was concluded into three points: 1) generally, the teaching material in Himmati was divided into 5 volumes, namely the introduction of letters, words, tajwid, gharib, and verses in the Qur'an. Each 
of them was presented by the inductive approach; 2) specifically, the teaching material in Himmati was divided into 7 volumes which are presented with examples from the Qur'an. The $1^{\text {st }}$ focuses on pronunciation, the $2^{\text {nd }} A$ on short vowels, long vowels, nunation, and original sukuun, the $2^{\text {nd }} \mathrm{B}$ on non-original sukuun and germination, the $3^{\text {rd }} \mathrm{A}$ on the law of nuun sukuun, nunation, germination nuun and miim, the $3^{\text {rd }} \mathrm{B}$ on the law of miim sukuun, definite article $a l$, and madd, the 4th on the rule of exception, and the $5^{\text {th }}$ on the stop sign. Each of them colored in the order of the frequency of visible light, from red to violet; 3 ) the teaching materials in Himmati were prepared for beginners with various ages and school grades, in the formal or non-formal institution. Further research can be done through the application of Himmati to increase the reading Qur'anic skill for beginners. Based on these results, this research has two implications. Theoretically, the selection of teaching material must be adjusted to the goal of teaching and the level of the student. Practically, Himmati is offered as a textbook for beginners in learning to read the Qur'an.

\section{ACKNOWLEDGMENT}

The researcher wishes to express her gratitude to her parents and her doctor (Misha Hd), Mr. Adil, dr. Christyjai, Ustadz Fuad, Syekh Kamba, Ustadz Hanifan, Mr. Santo, Merry, Fairuz, Dani as people who have major roles in helping to prepare Himmati, both materially and immaterially.

\section{BIBLIOGRAPHY}

Adriana, I. (2017). Perubahan Bunyi Pada Bacaan-Bacaan Gharib Dalam Alquran Menurut Tinjauan Fonologi Arab. OKARA: Jurnal Bahasa Dan Sastra, 11(1), 57-84. DOI: https://doi.org/10.19105/ojbs.v11i1.1238

Al-Daq, S. N. (2013). 'Adad ma fi al-Qur'an min Tikrar Huruf al-Mu'jam.

Retrieved from al-Alukah al-Syar'iyah website:

https://www.alukah.net/sharia/0/57490/

Al-Jamzuri, S. bin H., \& Al-Maraqi, A. M. bin A. (n.d.). Nail al-Anfal fi Tarjamah Tuhfah al-Athfal. Semarang: Toha Putra.

Al-Rajihi, A. (1995). Ilm Lughah al-Tathbiqi wa Talim al-'Arabiyah. Alexandria: Dar el-Ma'rifah el-Jami'ah.

Al-Ushaili, A. I. (2002). Tharaiq Tadris al-Lughah al-'Arabiyah li al-Nathiqin bi Lughat Ukhra. Riyadh: King Fahd.

Albab, U., Nuha, U., \& Maskan, M. M. (2004). Yanbu'a: Thoriqoh Baca Tulis dan 
Menghafal al-Qur'an. Kudus: Pondok Tahfidh Yanbu'ul Qur'an.

Alhamuddin, A., Hamdani, F. F. R. S., Tandika, D., \& Adwiyah, R. (2018).

Developing Al-Quran Instruction Model Through 3a (Ajari Aku Al-Quran or

Please Teach Me Al-Quran) To Improve Students' Ability in Reading Al-

Quran At Bandung Islamic University. International Journal of Education, 10(2), 95-100. DOI: https://doi.org/10.17509/ije.v10i2.8536

Anggara, S. A., \& Habib, M. T. (2018). Al-Usus al-Muhimmah fi Tathwir alMawadd al-Ta'limiyah fi Ta'lim al-Lughah al-'Arabiyah. Lughawiyyāt: Jurnal Pendidikan Bahasa Dan Sastra Arab, 1(2). DOI:

https://doi.org/10.38073/lughawiyyat.v1i2.133

Azaz, M. (2019). L1 Transfer Effects in the Production of Generic Plurals in L2 Arabic. ML: The Modern Language Journal, 103(1), 275-290. DOI:

https://doi.org/10.1111/modl.12542

Benitez-Correa, C., Gonzalez-Torres, P., Ochoa-Cueva, C., \& Vargas-Saritama, A. (2019). A Comparison Between Deductive and Inductive Approaches for Teaching EFL Grammar to High School Students. International Journal of Instruction, 12(1), 225-236. DOI:

https://doi.org/10.29333/iji.2019.12115a

Bharadwaj, V. (2017). Colours: A Scientific Approach. International Journal of Research - Granthaalayah: Composition of Colours, Desember(1), 1-6. DOI: https://doi.org/10.5281/zenodo.888063

Corder, S. P. (1973). Introducing applied linguistics: Penguin Education. Michingan: Penguin Books.

Effendy, A. F. (2005). Metodologi Pengajaran Bahasa Arab(3rd ed.). Malang: Misykat Indonesia.

Effendy, A. F. (2013). Sudahkah Kita Mengenal A/-Quran? Malang: Misykat Indonesia.

Farid, E. K. (2018). Tathwir al-Mawadd al-Ta'limiyah li Maharah al-Istima' li Daris al-Lughah al-'Arabiyah li ghair al-Nathiqin biha. ALSUNA: Journal of Arabic and English Language, 1(2), 114-120. DOI: https://doi.org/10.31538/alsuna.v1i2.79

Hakim, M. K. bin A. (2019). Needs Analysis of Arabic Guided Writing Material Using Task-Based Learning. Jurnal Al Bayan: Jurnal Jurusan Pendidikan Bahasa Arab, 11(2), 281-304. DOI: https://doi.org/10.24042/albayan.v

Humam, A. (1990). Iqro': Cara Cepat Mebaca al-Qur'an. Yogyakarta: Balai Litbang LPTQ Nasional Team Tadarus "AMM."

Islam, A. M. S. (2015). Faktor Demotivasi Pembelajaran Bahasa Arab. Arabiyât: Jurnal Pendidikan Bahasa Arab Dan Kebahasaaraban, 2(1), 1-16. DOI: https://doi.org/10.15408/a.v2i1.1511 
Istiqomah, H. (2019). "HIMMATI" as a Modification Base Learning to Identify Al-Qur'an. Proceeding of International Conference on Islamic Education (ICIED), 4(1), 84-89. Retrieved from http://conferences.uinmalang.ac.id/index.php/icied/article/view/1070

Istiqomah, H., \& Mahliatussikah, H. (2019). Musykilat al-Tarbiyyah Tuwajihuha al-Thalabah fi Ta'allum al-Lughah al-Arabiyah li Ghairi al-Nathiqin biha. Jurnal Al Bayan: Jurnal Jurusan Pendidikan Bahasa Arab, 11(2), 254-280. DOI: https://doi.org/10.24042/albayan.

Lubis, H., Lubis, S. A., \& Azmi, F. (2018). Teacher Competency on Learning AlQuran in Raudhatul Athfal At Medan. International Journal on Language, Research and Education Studies, 2(3), 312-321. DOI: https://doi.org/10.30575/2017/ij|res-2018091201

M Cloonan, M., \& Fingeret, A. L. (2020). Developing teaching materials for learners in surgery. Surgery, 1674), 689-692. DOI: https://doi.org/10.1016/j.surg.2019.05.056

Mahjoob, E. (2015). A Comparison of the Effectiveness of Inductive vs. Deductive Instruction of Grammar to EFL Students. Journal of Language, Linguistics and Literature, 1(5), 164-169. Retrieved from http://www.aiscience.org/journal/j3l

Mahmoud, H. N., \& Shaker, M. M. (2019). The Citation of the Speech of AlA'rab (Bedouin) in "Gharib Al-Qur'an": A Linguistic Study. Journal of Tikrit University for the Humanities, 26(3), 158-180. DOI: https://doi.org/10.25130/hum.v26i3.586

Mallia, J. G. (2014). Inductive and Deductive Approaches to Teach English Grammar. AWEJ: Arab World English Journal, 5(2), 221-235. Retrieved from www.awej.org

Manshur, A. M. S. A. (1980). IIm al-Lughah al-Nafsi. Riyadh: 'Imadah Syuun aMaktabat - Jami'ah al-Malik Sa'ud.

Marzouk, R., \& Kareh, S. El. (2018). An Evaluation of the Morphological Analysis of Egyptian Arabic TreeBank. In Intelligent Natural Language Processing: Trends and Applications (Vol. 740, pp. 637-658). DOI: https://doi.org/10.1007/978-3-319-67056-0 30

Mijlad, A., \& El Younoussi, Y. (2019). Arabic text diacritization: Overview and solution. ACM International Conference Proceeding Series, 1-7. DOI: https://doi.org/10.1145/3368756.3369088

Munif, M. (2018). Pendidikan Karakter Dalam Bahan Ajar Bahasa Arab Kelas 3 Madrasah Ibtida'iyah Kurikukulum 2013. Islamic Review: Jurnal Riset Dan Kajian Keislaman, 72), 137-157. DOI:

https://doi.org/10.35878/islamicreview.v7i2.142

Munjiah, M. (2012). Kaidah-Kaidah Imla' (Teori dan Praktik). Malang: UIN Maliki 
Press.

Nabhan, S. bin S., \& Al-Samarani, A. M. bin A. al-M. (n.d.). Syifa'al-Jinan fi Tarjamah Hidayah al-Shibyan. Surabaya: Maktabah al-'Ashriyah.

Otaya, L. G., Anwar, H., \& Husain, R. T. (2019). Estimating the Students' Skill in Reciting and Writing Al-Qur'an at Faculty of Tarbiyah and Teacher Training IAIN Sultan Amai Gorontalo. Nadwa : Jurnal Pendidikan Islam, 13(1), 7594. DOI: https://doi.org/10.21580/nw.2019.1.1.3590

Ryding, K. C. (2005). A Reference Grammar of Modern Standard Arabic. New York: Cambridge University Press.

Sadzili, H., Al-Ali, M. T., Masyhud, M., \& Muaffa, A. (2000). Tilawati: Metode Praktis Cepat Lancar Belajar Membaca al-Qur'an untuk TK/TP al-Qur'an. Surabaya: Pesantren al-Qur'an Nurul Falah.

Supriyadi, T., \& Julia, J. (2019). The problem of students in reading the Quran: A reflective-critical treatment through action research. International Journal of Instruction, 12(1), 311-326. DOI:

https://doi.org/10.29333/iji.2019.12121a

Taib, J. M., Yusof, N. M., Jamil, H. M. T., Aris, H. R., \& Satari, H. (2016). An Interactive Approach of an E-TajweedYaasin System. In Envisioning the Future of Online Learning (pp. 115-123). DOI:

https://doi.org/10.1007/978-981-10-0954-9 10

Thu'aimah, R. A. (1958). Dalil 'Amal fi I'dad al-Mawadd al-Ta'limiyah li Baramij Talim al-'Arabiyah. Makkah: Ma'had al-Lughah al-Arabiyah Jami'ah Ummul Qura.

Thu'aimah, R. A. (1986). Al-Maraji' fi Ta'lim al-Lughah al-'Arabiyah li al-Nathiqin bi Lughat Ukhra (J. 2). Makkah: Ma'had al-Lughah al-Arabiyah Jami'ah Ummul Qura.

Wahab, M. A. (2015). Pembelajaran Bahasa Arab Di Era Posmetodern. ARABIYAT: Jurnal Pendidikan Bahasa Arab Dan Kebahasaaraban, 2(1), 5974. DOI: https://doi.org/10.15408/a.v2i1.1519

Yeomans-Maldonado, G. (2017). Development of comprehension monitoring in beginner readers. Reading and Writing, 30(9), 2039-2067. DOI: https://doi.org/10.1007/s11145-017-9765-x

Yousfi, B., \& Zeki, A. M. (2017). Holy Qur'an speech recognition system Imaalah checking rule for warsh recitation. IEEE 13th International Colloquium on Signal Processing \& Its Applications (CSPA), 258-263. DOI: https://doi.org/10.1109/CSPA.2017.8064962

Zaghouani, W., Bouamor, H., Hawwari, A., Diab, M., Obeid, O., Ghoneim, M., ... Oflazer, K. (2016). Guidelines and framework for a large scale Arabic diacritized corpus. Proceedings of the 10th International Conference on 
Language Resources and Evaluation, LREC 2016, 10, 3637-3643.

Zarkasyi, D. S. (1989). Qiroati: Metode Praktis Belajar Membaca al-Qur'an. Semarang: Yayasan Pendidikan al-Qur'an Raudhatul Mujawwidin.

Zerrouki, T., Shquier, M. M. A., Balla, A., Bousbia, N., Sakraoui, I., \&

Boudardara, F. (2019). Adapting espeak to Arabic language: Converting Arabic text to speech language using espeak. International Journal of Reasoning-Based Intelligent Systems, 11(1), 76-89. DOI:

https://doi.org/10.1504/ijris.2019.098056 